\title{
Young People, Procedural Justice and Police Legitimacy in Nigeria
}

\author{
-Oluwagbenga Michael Akinlabi
}

\begin{abstract}
Most findings from developed western societies - particularly US and UK - have consistently found that young people's judgement about police legitimacy is built predominantly on procedural justice. Empirical investigations to test this assertion among youth from developing and less cohesive societies remain scarce. This article explores the possibility of closing this gap in literature. It assesses the strength of procedural justice effect in comparison with other police behaviour and inherent characteristics of young people in Nigeria. Using data collected from six secondary schools in Nigeria, the results substantiate the procedural justice hypothesis in the West; confirming that procedural justice is a more important predictor of police legitimacy than police effectiveness. The study also confirm that police legitimacy is further associated with other variables included in the analysis. The implications of these current findings are discussed.
\end{abstract}

Keywords: procedural justice, police legitimacy, young people, Nigeria police

\section{INTRODUCTION}

Attitude formation, either positive or negative, towards police and other legal institutions is predominantly developed during adolescence (Hinds, 2009). Attitudes formed during adolescence are argued to exert a lasting influence on judgments of police later in adulthood (Easton and Dennis, 1969). Findings on the legal socialization process from childhood to adulthood have recorded an often ‘conflict-prone’ relationship with police during adolescence, as young people challenge police authority and other social control institutions (Hinds, 2009; Clark and Wenninger, 1964).

The police represent the first encounter adolescents typically have with the legal system and, while relationships between police and young people have been characterised by conflict 
and low levels of trust in many developed western societies, explanations for why this is so remain typically understudied (Piquero et al., 2005; Sanders, 1981; Murphy, 2015; Leiber et al., 1998). For example, crime statistics in Australia reveal that young people are the most likely group to have frequent contact with the police, and persons aged 15 to 19 years are the most prominent group to have contact with police for the commission of a crime in comparison to older populations (Murphy, 2015).

Young people are more likely to attract police attention, in part because of their high level of involvement in illegal activity. This is because behaviours that are legal for adults may not be so for young people. Examples include alcohol consumption, temporary absenteeism from school, driving cars unlicensed (Ericson and Haggerty, 1997). Further, the greater likelihood of youth congregating in public areas and often being considered as public nuisance attracts unwanted police attention (Barclay et al., 2007). It is for these reasons that scholars have suggested youth view police with more scepticism than older people (Hinds, 2009; Murphy, 2015).

In the Nigerian context, it is unknown whether adolescents see police as legitimate and worthy of being deferred to. It is also unclear what characterises the perceptions of young people when they have contact with police officers in Nigeria. Given the different policing environment in a country like Nigeria it is important to examine whether findings in the West can be generalised to a Nigerian context. This is the focus of this research paper: to extend the procedural justice model into an under-explored context. Of particular interest will be how perceptions of procedural justice shape Nigerian adolescents' views of police as legitimate authorities that are entitled to be obeyed. 
Most findings have established that judgement about police legitimacy is built on the behaviour of police officers, especially how they wield authority (Tyler, 2006b; Jackson et al., 2014; Bradford et al., 2014). This paper has taken a further step to examine other factors that may be resident in the young people or in their socio-political environment which may have significant effect on their perceptions of police legitimacy. In other word, perceptions of police may be associated not only with what police do, but with a wider failure of government to provide for its citizens, thereby leading to public cynicism towards the police and political institutions (Bradford et al., 2014).

Also, studies have shown that legitimacy is negatively correlated with delinquency, moral neutralisation, and violent crimes (Eisner and Nivette, 2013; Nivette and Eisner, 2013; Ribeaud and Eisner, 2010). Moral neutralisation in this context is based on a set of mechanisms by which delinquents self-justify their acts of inflicting harm on others (Eisner and Ghuneim, 2013). It includes the notions that victim deserves to be harmed and punished, that victim is to blame for the aggression, that others in the same shoe as the delinquent would do the same, and that violence is a legitimate way of pursuing one's interests (Ribeaud and Eisner, 2010).

Although the norm in empirical literature is to assess legitimacy as a predictor of legal compliance or crime (Hough et al., 2013; Eisner and Nivette, 2013; Tyler and Huo, 2002), in this study, however, delinquency or moral neutralisation is not considered as consequences of legitimacy. Rather, this study explores how young people who reported prior delinquency and moral neutralisation evaluates police legitimacy. Prior studies have shown that delinquents often have negative evaluation of legal system (Piquero et al., 2005). Whether this conclusion hold true in the Nigerian context remain largely unknown. 
Police are the visible enforcer of law and important representatives of the state (Bradford et al., 2014). The legitimacy of police is often influenced by state activities and the public assessment of the state. As a result, there is always a spill-over effect, "not only about how officers of the law behave”, but the extent to which public acquiesce to the state. In a country like Nigeria, it is widely known that public perception of political office holders is not great. And that the failure of successive Nigerian governments to meet the needs of its citizens may not only undermine state’s legitimacy, but also weaken state's apparatus to sanction behaviour. Consequently, this study explores the link between political cynicism and police legitimacy by assessing whether young people who held cynical view about the state will also translate this view to the police.

Accordingly, the primary purpose of this paper is to examine the place of procedural justice theory in Nigerian youth's judgements about the police vis-à-vis other, possibly important, but competing variables.

Before presenting the findings of this current study; first, the relationship between procedural justice and police legitimacy is discussed. Then, a review of policing situation in Nigeria and the undermining effect of everyday corruption on its perceived legitimacy is also examined. And lastly, some of the empirical studies highlighting the importance of procedural justice effects to young people’s perceptions of police legitimacy are also reviewed.

\section{Police legitimacy and Procedural Justice}

The importance of police legitimacy to young people’s compliance with the law, police rules and decisions is an important area of research given the extensive contact between young people and police (Loader, 1996; Schuck and Rosenbaum, 2005; Hinds, 2009) and the wide discretionary 
powers available to police in their daily encounters with the youth (Cunneen and White, 2002). Legitimacy as a concept of power and political authority is viewed as the belief that legal authorities are entitled to be obeyed and that individuals ought to defer to their judgements (Tyler and Huo, 2002).

Legitimacy is the specific worth, value or respects which individual or groups ascribe to things they perceive as deserving their support. It is typically believed to emanate from the state of mind of the citizens or power subjects (Jackson et al., 2015; Bottoms and Tankebe, 2012; Tyler, 2006a) and in some ways refers to people's acceptance and recognition of legal institutions to hold power (Coicaud, 2002). Legitimacy exists when public accepts institution's claim to dictate appropriate behaviour and when the citizens feel they have corresponding duty to obey (Tyler, 2006b; Jackson et al., 2012). A government whose citizens or population considers it legitimate is a government that do not need to fear public defiance or insurrection. A state or government whose citizens denied its legitimacy will fail or falter in fulfilling their duties. To be effective in the discharge of their 'assigned' duties, legal authorities must have some form of legitimacy (Weber, 1947; Tyler, 2006b). Those who are subject to these authorities must see them as right and proper (Beetham, 1991; Matheson, 1987; Williams, 2003; Beetham, 2001).

A necessary condition of justifiable use of state power is the legitimacy of the police force (Tyler, 1990). The engagement of a state in promoting democratic norms can be readily seen in the way and manner its police uphold or respects these ideals. In essence, police are the litmus test of the 'democratic' ideals in any society. Although police are important representatives of the state, charged with enforcing the law, and expected to occasionally use the threats of force, it is evidently impossible for the police to be everywhere at all times. The police must therefore rely on public acquiescence and widespread law-abiding behaviour, so they could 
concentrate the available resources on those people in whom it is difficult to obtain compliance (Tyler, 2004; Hinds and Murphy, 2007). When there is widespread disregard and nonobservance of the law, the police resources are severely depleted and inadequate to maintain public order.

A legitimate police force demonstrates to citizens why its access to and exercise of power is rightful, and why those subject to its power have a corresponding duty to obey (Tyler, 2006b). Legitimacy is the fulcrum upon which the relationship between the police and the public rests (Sunshine and Tyler, 2003). In other word, to earn the support and approval of the public, police must prove they are legitimate. The police must demonstrate to the citizens why the public should obey, cooperate, and comply with their dictates. The fulfilment of this act by the police serves as the central link connecting the police to the public, which in turn helps in effective policing and social regulation.

Large body of research has demonstrated that two components, comprising procedural justice and police effectiveness, are of particular importance in promoting police legitimacy (Nagin, 1998; Tyler, 1990; Tyler \& Huo 2002). A major aspect of the procedural justice components include people's perceptions or judgements about the fairness of procedures used by police, while that of police effectiveness talks about effectiveness of the police in discharging their duties in areas of security and crime control.

Police effectiveness as a concept, generally reflects an instrumental motivation to legitimise the police. It is predominantly focused on how well police do their job. How well they deter people from breaking the law, detect crimes, and arrest those who break the law. The idea embedded in effective policing is that people legitimise police authority when they can relate 
with the external promise of crime reduction, strong deterrence, police efficiency, and social control (Sunshine and Tyler, 2003).

Procedural justice on the other hand is mostly concerned with making decisions that are based on fair procedures. Procedural justice engenders support for police when the public perceives that the procedures adopted by the police treat them with dignity and respects. Procedural justice approach to policing allows the police to focus on crime control without being disrespectful or alienate the public (Tyler, 1990). A fundamental element in procedural justice model of policing is quality of treatment. The quality of treatment expected by the public involves police being polite and courteous, treating the people with respect and dignity, giving voice to the people to express their concerns, and being the neutral and unbiased enforcers of the law in every encounter or interaction with the public (Davies et al., 2014; Tyler and Murphy, 2011; Sunshine and Tyler, 2003).

Procedural justice is also believed to be relational in nature, because it provides feedback about the quality of treatment and relationship between the police and the public (Mastrofski et al., 1996; Mazerolle et al., 2012; Tyler and Lind, 1992), and it also tends to inspire feelings of group loyalty, voluntary compliance and cooperation, and it legitimises the authority of the police (Bradford and Jackson, 2010; Cherney and Murphy, 2011; Sunshine and Tyler, 2003).

Findings, mostly in the West, have consistently shown that police-citizen encounters involving elements of procedural justice is more beneficial and has led citizens to be more satisfied with the interactions and the outcomes of such encounters (Tyler and Fagan, 2008; Mazerolle and Martin, 2012; Mazerolle et al., 2013; McCluskey, 2003) than with judgement about other aspects of police behaviour - notably, about police effectiveness (Murphy, 2015; Tyler, 1990; Tyler, 2006b; Tyler and Huo, 2002; Sunshine and Tyler, 2003). 
Although this conclusion seems very appealing, it however, has a fundamental flaw; the procedural justice approach has only received scant empirical investigations in non-western and transition societies where there are fragile political systems, weak social orders, high record of police abuse, and incessant corruptions. The few existing studies have reported inconsistent results, with effects of procedural justice being reported by some (Tankebe, 2009b; Reisig and Lloyd, 2009; Davies et al., 2014; Kochel et al., 2013), and possible boundary effects by others (e.g., Tankebe, 2009a; Bradford et al., 2014; Jackson et al., 2014). This suggests that the applicability of the procedural justice model in non-western context is not without limit and that under some socio-cultural conditions, it might become less predictive of police legitimacy. As a result, the overarching goal of this paper is to investigate whether there will be any procedural justice effect on the perceptions of police legitimacy in a non-western society such as Nigeria.

Beyond this issue of transcultural applicability, procedural justice research has been tested only in few studies focusing on young people and adolescents. Existing studies have highlighted the difficulties involved in engaging young people in collaborative crime control efforts with the police (Murphy, 2015). This is because young people often hold less favourable assessments of the police when compared to the adults. These studies have also reported that procedural justice can foster collaboration and enhance legitimacy when the police interacts with young people and adolescents (Reisig et al., 2012; Reisig and Lloyd, 2009; Murphy, 2015; Fagan and Tyler, 2005; Piquero et al., 2005; Dirikx and Van den Bulck, 2014).

\section{Legitimacy and Police Corruption in Nigeria}

Corruption is endemic in Nigeria and it pervades all levels of the society. Nigerians are very swift in condemning corruption; paradoxically, they are also active participants in its social 
reproduction. Everyday practices of corruption in government and the narratives of how ordinary Nigerians are complicit in its cover-up will make Nigeria a loathsome place to an "outsider". Nigerians are participants in perpetuating corruption in their own society. They do so, mostly in circumstances that are beyond their control. In many instances, citizens succumb to corrupt demands due to societal inequalities and the pressure to access basic services.

It is commonplace, as Smith (2007) stresses, for government officials, by virtue of their position, to demand bribes from ordinary Nigerians before services are rendered. Anyone who refuses to give bribe, and has no connection with someone in government or knows an influential person, is routinely subjected to unnecessary delays or eventual denial of such services. Although they routinely complain and talk about these experiences, a large proportion of the population see bribe-paying as a channel to otherwise scarce and inaccessible services. This attitude is what, Leff (1964), referred to as the efficient grease theory.

Efficient grease theory offers a formal illustration that corruption may be beneficial in some countries where governance is mediocre; by alleviating distortions, scarcity, and cost of time spent in queues, caused by ill-functioning institutions (see Huntington, 2006; Leff, 1964; Leys, 1965). Importantly, Leys (1965) asserts that bribe-paying is the bureaucratic incentives that speed up otherwise sluggish administration.

In Nigeria, the explanation for corruption requires an understanding of complex intersection of local culture and the larger system of favouritism and inequalities. When Nigerians discuss corruption, it is mostly in a broad sense inclusive, but also different from the western definitions of corruption. In Nigeria, corruption is not only referred to the abuse of state power for private gain but also a whole range of socially undesirable behaviours, in which morally questionable deceptions enable an individual or group to achieve wealth, power, 
prestige, and influence. This includes anything from government graft, electoral frauds, fraudulent businesses, and cheating in school, to the diabolical abuse of occult powers, internet scam, and police extortions (Alemika, 2010; Smith, 2007; Dike, 2005; Osoba, 1996).

Though corruption in its many valences pervades all institutions in Nigeria, the institution with worst records, whose name is synonymous with corruption (at least, in public perceptions) is the Nigeria Police Force. Police corruption is a major concern in Nigeria. It often takes many forms ranging from refusal to investigate reported cases, nepotism, cronyism, and extortion, to improper arrests, delayed prosecution of suspects, supply of guns to criminals, and direct involvement in robbery (Alemika and Chukwuma, 2003; Aremu et al., 2009; Human Rights Watch, 2010). There is a deep-rooted public hatred for the police, as they are sometimes, seen as beyond redemption.

High ranking police officers have been implicated in series of scandals and abuse of office, rank and files are known for their routine extortions at police check-points. According to Newburn (1999), police corruption is pervasive, continuing and not bounded by rank or a few rotten apples within the police organisation, and neither is it limited to one nation or state. Accordingly, corruption is seen as one of the highest reported cases of police misconduct in Nigeria and this has over the years undermined the legitimacy of police in Nigeria (Human Rights Watch, 2010; Smith, 2007).

Studies have shown that corruption undermines police legitimacy (Seligson, 2002; Newburn, 1999; Tankebe, 2010). In his historical account of police crises in Nigeria, Alemika (2010) asserted that a large number of police officers are corrupt and this is evident in their daily interactions with citizens. It is commonplace to see police officers receive, by virtue of their positions, an actual or potential unauthorized material reward from either offenders or victims of 
crime (see Alemika, 1988; Alemika, 2010; Aremu et al., 2009). The Nigerian police have a long history of engaging in unprofessional, corrupt, and criminal conduct, and using excessive and often brutal force (Alemika and Chukwuma, 2003; Tamuno, 1970; CHRI Report, 2005).

Through years of neglect and marginalization under military rule, followed by rapid expansion during Nigeria's civilian administrations, the police force has grown into a notoriously corrupt institution that is largely unaccountable to the people it is intended to serve (Alemika, 2010; Agbu, 2003; Odunsi, 2005; Alemika and Chukwuma, 2003; Aremu et al., 2009). It is not unusual to hear some members of the public address police with names such as Askari (corrupt), Egunje (bribe), and Roja me (grease my palm) on seeing a police officer at a close distance (Akinlabi, 2011).

In a study conducted by Human Rights Watch (2010) using samples from 145 victims and witnesses of police corruption in Nigeria, the research confirmed that corruption and abusive behaviour within the Nigeria Police Force is endemic. Similarly, Seligson (2002) tested the corruption-legitimacy hypothesis in nineteen Latin American countries. He found that higher experience with corruption was significantly associated with lower support for the legitimacy of the political system across the countries. There are good reasons to expect this same result to be true in the Nigerian context with respect to police. Public experiences and perceptions of police corruption have also been established as a precursor to low or lack of public trust in the police and a perceived lack in police legitimacy (Tankebe, 2010).

Another important debilitating effect is that corruption has a negative impact on police effectiveness. As the police become identified with ineffectiveness as a result of corruption, public normative commitments to them and their readiness to consider the police as legitimate 
arbitrators of disputes will diminish (Tankebe, 2007). These patterns highlight the serious corruption challenges facing Nigeria and its police.

As much as these concerns are acute in Nigeria, it should be noted that most of the existing studies, interestingly, focused on adult samples (Human Rights Watch, 2010; Osoba, 1996; Hills, 2008; Zimring and Johnson, 2005), with little attention to how young people perceive or defer to police authority. Also, there is currently no record of research efforts in the area of police legitimacy from Nigeria. Given the widespread existence of police corruption and the disproportionally high chance of a negative encounter with police in Nigeria, it is important to test whether perception of police legitimacy will matter to the young people.

\section{Youth and Procedural Justice Policing}

There is a growing body of research, mostly from the developed western societies, confirming that encounters between youth and police can be strengthened if police can utilise procedural justice when dealing with adolescents and young people (Piquero et al., 2005; Dirikx and Van den Bulck, 2014; Reisig et al., 2012; Reisig and Lloyd, 2009; Murphy, 2015; Fagan and Tyler, 2005).

Currently little is still known about how procedural justice shapes young people's perceptions of police legitimacy, particularly in non-western jurisdictions. Vast number of studies published in this field have been conducted with data collected from adult samples. These studies typically show that procedural justice is more important than police effectiveness in shaping public perceptions of police legitimacy (see Sunshine and Tyler, 2003; Mazerolle et al., 2013) and willingness to cooperate with police (see Tyler and Fagan, 2008; Tyler and Huo, 
2002; Tyler and Murphy, 2011); important exceptions being Tankebe (2009a) in his Ghana study and Sargeant et al. (2014) for ethnic minority groups in Australia.

Since the focus of this study is on young people’s perception of police legitimacy, some of the existing studies on youth and adolescents will be reviewed. For example, in a study conducted by Piquero et al. (2005) where they focused on the legal socialization of 1355 juvenile offenders, they found positive procedural justice effects for the perceptions of police legitimacy. However, when compared to White offenders, African-American offenders were less likely to see police as legitimate. Piquero et al. (2005) also found effect for gender on perceived legitimacy, in which females were found to be more likely to rate police with higher legitimacy. Finally, Piquero and his colleagues reported that positive procedural justice perceptions of police were positively associated with lower legal cynicism and higher perceptions of police legitimacy. This study was important, as it was the first to demonstrate that adolescents put value on normative factors in shaping their view of the legal system and legal authorities.

Similarly, Fagan and Tyler (2005) found that the perceived legitimacy of the police shaped compliant behaviours in adolescents, supporting results from the adult literature (see Tyler, 2006b; Sunshine and Tyler, 2003). It was also found that adolescents who viewed police as being fair in their procedures had better perceptions of police legitimacy.

Considering findings from other jurisdictions such as Australia, it is interesting to note that the results support those studies in the United States. For example, Hinds (2007) conducted the first non-US study on the relationship between young people, police legitimacy and procedural justice in Australia. Hinds (2007) collected survey data from 328 high school students aged 14 to 16 years. The study established that young people's views of police legitimacy were 
positively linked to police use of procedural justice as well as their effectiveness in handling crimes and crime situations.

Recently, Murphy (2015) compared a data collected from 513 Australian high school students with 2611 adults in Australia. Murphy found that perceptions of procedural justice shaped youth's willingness to engage and cooperate with police. Her results provided further support for US findings (i.e., Piquero et al., 2005; Fagan and Tyler, 2005). Murphy also found that procedural justice is in fact more important to youth than it is to adults in fostering collaboration with police (see also Murphy and Gaylor, 2010).

Thus far, few youth studies from transitional societies like Jamaica has shown that correlation between procedural justice judgements and police legitimacy is positive and statistically significant. Drawing on the process-based model, Reisig and Lloyd (2009) uses survey data from a sample of 289 Jamaican high school students to evaluate the link between procedural justice and police legitimacy. The study revealed that students who rate police practices more favourable in terms of procedural justice policing, also report tendency for perceived police legitimacy, and willingness to help police fight crime in their community. This finding show that the process-based model hypothesis of the US study can be generalise to the Jamaican context.

In summary, these studies demonstrate that when fair procedures are utilized by the police, it can influence young peoples' perceptions of police legitimacy. This policing approach is important as it gives police control over outcomes. Police may not be able to control the crime rate and the resources available to them, but, they can control how they treat young people with whom they come into contact. 


\section{THE PRESENT STUDY}

Given the preceding arguments about policing situation in Nigeria, it remains an empirical question to ascertain whether young people in such a society will employ normative judgements about fair procedures when aligning themselves toward the police. Undoubtedly, many factors may crowd out procedural fairness, including concerns about police corruption, effectiveness in security and crime control, and the cynicism about politicians and political institutions. These factors may as well transcend situational factors to issues more associated with the individual adolescents, such as previous experiences/contact with the police, delinquency, and moral neutralisation.

For this reason, the first hypothesis in this current study is, primarily, to flesh out the place of procedural justice in Nigerian youths' judgements about the police. It has been established from Western studies that young people will likely view police as legitimate when they have been treated with fair procedures (e.g., Piquero et al., 2005; Hinds, 2007; Murphy, 2015; Fagan and Tyler, 2005). A number of scholars have argued, however, that this may not hold traction across all conditions and contexts (e.g., Tankebe, 2009a; Sargeant et al., 2014; Bottoms and Tankebe, 2012; Murphy and Cherney, 2011; Bradford et al., 2014). For example, a study conducted by Tankebe (2009a) has shown that in the Ghanaian context, instrumental dimensions such as police effectiveness are far more important in predicting police legitimacy than procedural justice. Further, Sargeant et al. (2014) found that for some ethnic minority groups in Australia, police effectiveness matters more than procedural justice. One might expect therefore that youth in Nigeria may focus more on police effectiveness than procedural justice. 
Second, studies have shown that corruption undermines police legitimacy (Newburn, 1999) and that corruption can strengthen citizen trust in a corrupt regime when a large proportion of the population believe that bribe-paying opens door to otherwise scarce and inaccessible services (Leff, 1964). In other words, a citizen faced with ill-functioning institutions will place greater trust in the political institutions if he knows that corruption is a way to get what he wants (see Lavallée et al., 2008). Accordingly, one might be tempted to assume, therefore that since Nigerian youth are faced with endemic corruption, they might be less affected by corruption than individuals in a less corrupt society. That is, because they are used to the corrupt system, it may have become normalised and therefore might not affect legitimacy perceptions. It is hypothesised therefore that perceptions of police corruption among Nigerian adolescents will have significant negative effect on perceptions of police legitimacy. That is, higher perceptions of police corruption will be negatively related to perceptions of legitimacy.

Third, and in line with previous argument on Nigerian corruption, this study hypothesise that it is most likely that the young people will hold a cynical view about the prevailing political instability and failure of government to provide for its citizens.

Fourth, 'personal experiences with the police' will also be examined to know how well these experiences predict young people's legitimacy perceptions. Since Nigeria is a highly corrupt society with a police service known for its routine abuse, brutality, and corrupt practices, it is hypothesised that the youths' past experiences with the police will negatively predict their perceptions of the police.

Fifth, other factors that may likely resident in the adolescence such as delinquency and moral neutralisation will be assessed to ascertain their effects on young people's judgement of 
police legitimacy. It is hypothesised that adolescents who report high delinquency and high moral neutralisation will be less likely ascribe legitimacy to the police.

Lastly, this study will examine whether procedural justice is still able to predict police legitimacy when the effects of other variables have been controlled for. If how police treat people is still significant for police legitimacy, even after controlling for these factors, then procedural justice will be an important concept to be instilled in police officers in countries like Nigeria.

\section{METHOD}

\section{Research Site}

The data for this study were collected in the first quarter of 2012 in Ibadan, south-west geopolitical zone of Nigeria. The main rationale behind the targeting of participants in Ibadan was, because as a cosmopolitan city, Ibadan is broadly populated by the Yoruba-speaking ethnic group with a great influx of migrants from other parts of the country such as the Hausas and Igbos. This is because Ibadan is the capital of the defunct Western region of Nigeria and is known for its rapid social, educational, and infrastructural development. Unlike some other parts of Oyo State which are mainly dominated by traditional and strong Yoruba cultural practices, Ibadan represents an accurate reflection of the cultural and ethnic diversity of the people of Nigeria.

Ibadan people are known for their tolerance and peaceful co-existence with other ethnicities and immigrants. People with different ethnic backgrounds, varied levels of education,

occupations, different socio-economic status, and espousing different religious beliefs, can be 
found in this city (OYSG, 2013; Mabogunje, 1967). Also, secondary schools enrolments in Ibadan comprise all the three major ethnicities in Nigeria. Unlike other states in Nigeria or other local government areas in Oyo State, students can be easily accessed in Ibadan. Thus, the heterogeneity within the seemingly homogeneous society makes Ibadan ideal for the present study especially for a study that aims to generalize its findings to the larger adolescent population in the country. This is, however, not a strong reason to see these data as truly representative of Nigerian adolescents. While one should be cautious with the generalizability of the data, the sampling and administration of the questionnaire was carried out in an unbiased manner and it is relatively representative of the adolescent population.

\section{Participants}

This study employed a quantitative approach for data collection, using a cross-sectional survey design. The research was conducted in accordance with the ethical code of practice as laid down by the British Society of Criminology (http://www.britsoccrim.org/codeofethics.htm). Parental approval was sought before involving the participants in the study. Participants' identities were protected and personalized information was handled with utmost confidentiality.

The sample in this study was collected in six senior secondary schools, from 305 students comprising 170 (55.7\%) males and 135 (44.3\%) females aged between 13 and 18 years (age: $M$ $=15.13, S D=1.23)$. This age range depicts that they were typically youths, making them suitable for this study. The family type of the respondents showed that 52.1 per cent $(N=159)$ are from parents who practiced monogamy, while $47.9 \%(N=146)$ are from polygamous homes. The ethnic composition of the sample was defined across the major ethnic groups as 
follows: $54.8 \%$ Yoruba $(N=167)$ respondents, $16.4 \%$ Hausa $(N=50)$ respondents and $28.9 \%$ Igbo $(N=88)$ respondents.

The family situation of the adolescents reveals that $78.0 \%(N=288)$ lived with both parents; $6.2 \%(N=19)$ lived with one parent as a result of divorce; $2.0 \%(N=6)$ lived with one parent because the other was deceased; and $13.8 \%(N=42)$ lived with guardians. This large proportion (13.8 \%) of adolescents living with guardians is a typical condition in Nigeria, but uncommon in western developed society. In the Nigerian context, there are several factors such as access to good education, parent's death, and poverty that can make living with guardians inevitable. For each respondent, the number of siblings reported ranged between 1 and 8 ( $M=$ 3.29, $S D=1.49)$. The number of people living in each household ranged between 2 and $11(M=$ $5.86, S D=1.52)$.

\section{Procedure}

Due to time constraints and bottlenecks at the Ministry of Education, the researcher could not obtain a list of secondary schools in Ibadan. However, the researcher randomly selected six senior secondary schools where the survey was administered. The Principals [Head of School] of the six schools were contacted to seek approval to use their school for the study. The six Principals all agreed to allow their students to participate in the study subject to parental approval.

From each school, a systematic random sampling technique was adopted in which samples from the total population of senior students between the ages of 13 and 18 were drawn. The school attendance register was used to select the sample, and the serial numbers in the 
register were assigned to the students. Thereafter the total numbers of students in the senior classes were divided by the number of cases required for the sample. This division yields the sample interval. The first student was selected randomly from the register, and then every $n t h^{1}$ number on the register was systematically selected thereafter. The researcher was able to draw out a total of 315 students, and thereafter gave them consent forms to obtain parental approval from their parents.

Three days after giving out the consent forms, the researcher returned to each school to administer the survey. A total of 305 students received parental approval to participate in the survey, making a total of $96.8 \%$ retention rate. One research assistant was recruited to assist in administering and collecting the questionnaires. In each school, the head teacher or principal also appointed one of the teaching staff to work with the researcher during the sampling of the students and administration of the questionnaires. The participants were grouped in a separate classroom from other students and the purpose of the study was reiterated before the questionnaires were administered.

\section{Measures}

This research paper utilised a range of measures to address the issues at hand. These measures are described below and Appendix A shows the full questions, mean and standard deviation of each items.

\footnotetext{
${ }^{1}$ The $n^{\text {th }}$ term here varies from the $3^{\text {rd }}, 4^{\text {th }}$, and the $5^{\text {th }}$ number in the class register across each of the schools.
} 


\section{Police Legitimacy}

How should police legitimacy be measured or operationalised? Current theorizing about police legitimacy has been shaped heavily by Tom Tyler, whose vital contribution is on the process-based model of regulation. Tyler's conceptualisation of legitimacy varies across most of his studies, with central components being obligation to obey, institutional trust, cynicism about the law, institutional support, and affective feelings (see Sunshine and Tyler, 2003; Tyler and Huo, 2002). Thus, one or more of these measures feature prominently in other empirical findings that replicates Tyler's work in other jurisdictions (Tankebe, 2009a; Hinds and Murphy, 2007; Kochel, 2012). Recently, however, there have been criticisms about the measurement and conceptualisation of legitimacy as prescribed by Tyler (Bottoms and Tankebe, 2012; Tankebe, 2013).

Tankebe (2013) argued that legitimacy should not be equated with felt obligation to obey legal authorities. The problem of equating legitimacy with obligation, according to Tankebe, can be seen in a situation where individuals felt an obligation to obey police out of a sense of endemic powerlessness, resignation, and fear of the consequences of doing otherwise, or what Carrabine (2004:180) referred to as "dull compulsion". In such a situation, Tankebe asserts that obligation can be misconstrued by police organisation to mean deference or a widespread perception of legitimacy.

This concern cannot be overlooked, but after decades of criminological research, there has not been a consensus agreement on how to measure or operationalise legitimacy. However, in this study because the data were collected during the first quarter of 2012, this current debate was not taken into consideration. When the data was collected, legitimacy was operationalised using three constructs: obligation to obey, trust in the police, and cynicism towards the law. 
Specifically, the legitimacy scale was adapted from the work of Tankebe (2009a). It taps into the notion that police is legitimate when public defer to its authority based on; (1) perceived obligation that police should be obeyed, (2) public trust in the institution of policing and in individual police officers, and (3) whether public perceives the police as wielding their authority against them and their interest. In this study, the three construct is combined into one composite scale. The scale has a Cronbach's reliability score of $\alpha=0.86$ with a mean score of 2.12. The responses on the scale were measured on a four-point Likert-type scale ranging from strongly disagree (1) to strongly agree (4). A high score on the scale reflects greater perceptions of police legitimacy.

\section{Procedural Justice}

Procedural justice was examined using a 12-item scale adapted from Tankebe (2009a) and Sunshine and Tyler (2003). The scale was measured on a four-point Likert-type scale ranging from (1) 'strongly disagree' to (4) 'strongly agree'. For this study, the scale has a Cronbach's reliability of $\alpha=0.78$ and mean score of 1.69. Young people were asked about their views on police use of fair procedures when dealing with them and people around them. The scale has items such as, "The police treat everyone with respect" and "Police give people the opportunity to express their views before decisions are made”. A higher score on the scale reflects more positive perceptions of police's use of fair procedures. 


\section{Police effectiveness}

Police effectiveness was measured using a 10-item scale adapted from (Tankebe, 2009a; Tankebe, 2010). The scale was measured on a four-point Likert-type scale ranging from 'strongly disagree’ to ‘strongly agree'. The scale had a Cronbach's alpha of $\alpha=0.76$ with a mean score of 1.51. Items such as, "The police are doing well in controlling violent crime (e.g. armed robbery)" and "The police respond promptly to calls about crime (e.g. robbery, assault)" were included in the scale. A higher score on this scale indicates that the respondent perceive the police as effective in discharging their duties.

\section{Police corruption}

Police corruption was measured using an eight-item scale adapted from (Tankebe, 2010; Tankebe, 2009a). It was developed to assess respondents' perceptions of police corruption. The scale was measured on a five-point scale, ranging from (1) 'not at all' to (5) 'very often'. For this study, the scale yielded a Cronbach reliability of $\alpha=0.81$ and means score of 1.98 respectively. The higher the individual's score on the scale, the greater their perceptions of police corruption. For example, the items are worded in a similar pattern as such: "Nigeria police are corrupt" and "Nigeria police extorts money from people".

\section{Delinquency}

Delinquency was included in the analysis because one might expect that it will affect how police are viewed. It was measured with a 12-item scale developed by the researcher. This scale was developed for cultural relativity purposes, as most of the western instruments would not be culturally fair in the Nigerian context. For example, concepts such as 'graffiti' and 'date rapes' have not been found in the vocabulary of Nigerian adolescents. The scale includes items such as 
'Not attended school without your parent's knowing', 'Used counterfeit money to pay for something', and 'Stolen something from the market, in a shop or a supermarket'. The scale was measured on a five-point scale ranging from 'Never' to '10 times and above'. The scale had a Cronbach's alpha of $\alpha=0.81$ as its reliability coefficient with a mean score of 1.53. A higher score on this scale indicates that the adolescent is more likely to participate in delinquent activities.

\section{Moral Neutralisation}

Moral neutralisation was added to the analysis to ascertain whether adolescents who have the tendency to "turn off" their internal moral control, or who can morally neutralise their delinquent behaviour, will perceive police as legitimate or otherwise. This construct was measured with a scale comprising 15 items. This scale was modified from Ribeaud and Eisner (2010) scale to suit this study. Questions such as 'Only a coward would ever walk away from a fight' and 'Getting bullied helps make people tougher' was included in the scale. The scale was measured on a four-point Likert-type scale ranging from 'fully disagree' to 'fully agree'. The scale had a Cronbach's alpha of $\alpha=0.94$ with mean score of 2.11. A higher score in the scale indicates that the respondents have a high tendency to morally justify their actions.

\section{Experience with Police}

This scale was included in the analysis because one might believe previous experience with police, either positive or negative might influence how police are viewed or perceived. This construct was measured using an 8-item scale. The scale was measured on a five-point scale ranging from (1) 'No' to (5) more frequently response format. The scale had a mean score of 
1.45 and a Cronbach's alpha of $\alpha=0.71$ respectively. Items such as, "Have you been stopped by the police on the street or on the way to school", "Have you ever been arrested" were included in the scale. A higher score on this scale shows respondents had more experience or more encounters with the police.

\section{Political cynicism}

Political cynicism was measured with a four-item scale. It was developed by the author to assess the extent to which the young people hold politicians in disrepute. The items in this scale is similar to the ones in Piquero et al. (2005) on legal cynicism. For this study, the scale yielded a mean score of 2.72 and Cronbach reliability of $\alpha=0.90$. Items such as, "Nigerian politicians make promises during campaign and never fulfil their promises after winning the election” were included in the scale. The scale was measured on a four-point Likert type ranging from (1) strongly disagree to (4) strongly agree.

Demographic variables: Some demographic variables were also included as controls in the regression analysis, which include age, gender, ethnicity, and religion.

\section{Limitations and suggestions for further studies}

A major strength in this study is that it is the first to examine the importance of procedural justice policing to people in Nigeria. It is also the first to examine the relationship between procedural justice policing and police legitimacy among young people in Africa. This 
study has also added new knowledge to a very scarce procedural justice literature in Africa. While the findings are important and have implications for police practice in Nigeria, it is however not immune from a number of limitations.

First, this study utilised a cross-sectional survey in the data collection processes. As such, the causal relationship between variables cannot be firmly established. For example, perhaps those who viewed police as less legitimate were less likely to rate police as using procedural justice. Longitudinal survey data or experimental studies using the same variables would possibly offer more effective grounds for determining causality between key variables of interest. A further limitation is the sample used in the study. The data for this study was not fully representative of young people in the six geopolitical zones in Nigeria. It would be helpful to consider a large-scale representative survey of young people in near future.

\section{RESULTS}

Analyses were conducted using IBM SPSS Statistics version 22. Specifically, bivariate correlations (i.e. Pearson product-moment correlation) and hierarchical multiple regressions were adopted in the analyses.

\section{Bivariate Correlations}

Table 1: Descriptive Statistics and Correlations

\begin{tabular}{|c|c|c|c|c|c|c|c|c|c|}
\hline & & 1 & 2 & 3 & 4 & 5 & 6 & 7 & 8 \\
\hline 1 & Legitimacy & 1 & $-.147^{*}$ & $.131^{*}$ & $-.265^{* *}$ & $-.250^{* *}$ & $-.208^{* *}$ & .026 & $.144^{*}$ \\
\hline 2 & Delinquency & & 1 & $.279 * *$ & $.461^{* *}$ & $.319 * *$ & $.550 * *$ & $.153^{* *}$ & .058 \\
\hline 3 & Moral neutralisation & & & 1 & $.242 * *$ & .053 & $.291^{* *}$ & .031 & -.107 \\
\hline 4 & Experience with police & & & & 1 & $.265^{* *}$ & $.508^{* *}$ & -.022 & $-.135^{*}$ \\
\hline 5 & Political cynicism & & & & & 1 & $.171^{* *}$ & .032 & $.137^{*}$ \\
\hline
\end{tabular}




\begin{tabular}{|c|c|c|c|c|c|c|c|c|c|}
\hline 6 & Police corruption & & & & & & 1 & -.111 & -.035 \\
\hline 7 & Police effectiveness & & & & & & & 1 & .111 \\
\hline \multirow[t]{5}{*}{8} & Procedural justice & & & & & & & & 1 \\
\hline & Mean & 2.12 & 1.53 & 2.11 & 1.45 & 2.72 & 1.98 & 1.51 & 1.69 \\
\hline & SD & 0.53 & 0.40 & 0.67 & 0.33 & 0.87 & 0.43 & 0.34 & 0.32 \\
\hline & Cronbach's Alpha & 0.86 & 0.81 & 0.94 & 0.71 & 0.90 & 0.81 & 0.76 & 0.78 \\
\hline & $\mathbf{N}=305$ & & & & & & & & \\
\hline
\end{tabular}

Note, statistical significance: ${ }^{*} p<.05 ;{ }^{* *} p<.01$

A Pearson product-moment correlation coefficient was computed to assess the relationship among the variables and the results are presented in Table 1 . It was found that there are significant correlations between most of the variables. Specifically, procedural justice was found to be positively correlated with police legitimacy $(\mathrm{r}=.144, \mathrm{p}<0.05)$, but police effectiveness was not significantly related to legitimacy $(r=0.26, p=n s)$. The variable with the strongest relationship with police legitimacy was experience with police $(r=-0.265, \mathrm{p}<0.01)$, such that those with more experience viewed police as less legitimacy.

\section{Hierarchical Multiple Regression Analyses}

Prior to conducting a hierarchical multiple regressions, preliminary analyses were conducted to ensure that no assumptions was violated. The sample size was adequate and the assumption of singularity was also met as the independent variables were not a combination of other independent variables (Tabachnick and Fidell, 2013). An examination of the correlation analysis (see Table 1) revealed that no independent variables were highly correlated. The collinearity statistics (i.e., Tolerance and VIF) were all within statistically acceptable limits, 
which means assumption of multi-collinearity have been met (Tabachnick and Fidell, 2013; Pallant, 2010; Field, 2013).

A four stage hierarchical multiple regression was performed to investigate the ability of procedural justice and police effectiveness to predict perceptions of police legitimacy after controlling for delinquency, moral neutralisation, experiences with police, political cynicism, and perceptions of police corruption (standard coefficients are presented). In the first stage of the hierarchical regression, four socio-demographic variables (age, gender, ethnicity, and religion) were entered. This model was not statistically significant; no demographic variables predicted perceptions of police legitimacy. After entry of delinquency and moral neutralisation at the stage two of the analysis, the total variance explained by the model was $6 \%[F(6,297)=3.056 ; p<$ .01]. Those who self-reported engaging in more delinquency were less likely to view police as legitimate.

Table 2: Hierarchical Multiple Regression Model of Police Legitimacy

\begin{tabular}{|c|c|c|c|c|c|c|c|}
\hline & Variable & $\bar{\beta}$ & $t$ & $\boldsymbol{R}$ & $R^{2}$ & $\Delta \boldsymbol{R}^{2}$ & $F$ \\
\hline Step 1 & & & & .070 & .005 & .005 & .364 \\
\hline & age & .064 & 1.094 & & & & \\
\hline & Gend er & -.029 & -.496 & & & & \\
\hline & ethnicity & .017 & .289 & & & & \\
\hline & religion & .005 & .079 & & & & \\
\hline Step 2 & & & & .241 & $.058 * * *$ & .053 & $3.056 * *$ \\
\hline & age & .063 & 1.102 & & & & \\
\hline & gender & -.022 & -.375 & & & & \\
\hline & ethnicity & .013 & .219 & & & & \\
\hline & religion & -.009 & -.151 & & & & \\
\hline & Delinquency & $-.203^{* * *}$ & -3.454 & & & & \\
\hline & Moral Neutralisation & $.181^{* *}$ & 3.038 & & & & \\
\hline Step 3 & & & & .406 & $.165 * * *$ & .107 & $6.464 * * *$ \\
\hline & age & .061 & 1.099 & & & & \\
\hline & gender & -.036 & -.653 & & & & \\
\hline & ethnicity & .004 & .069 & & & & \\
\hline & religion & -.030 & -.561 & & & & \\
\hline & Delinquency & .023 & .337 & & & & \\
\hline
\end{tabular}




\begin{tabular}{|c|c|c|c|c|c|c|c|}
\hline \multirow{16}{*}{ Step 4} & Moral neutralisation & $.223^{* * *}$ & 3.872 & \multirow{16}{*}{.439} & \multirow{16}{*}{$.193^{* *}$} & \multirow{16}{*}{.027} & \multirow{16}{*}{$6.331^{* * *}$} \\
\hline & Experience with police & $-.221 * * *$ & -3.356 & & & & \\
\hline & Political Cynicism & $-.190 * * *$ & -3.328 & & & & \\
\hline & Police Corruption & $-.138 *$ & -1.974 & & & & \\
\hline & & & & & & & \\
\hline & age & .062 & 1.131 & & & & \\
\hline & gender & -.039 & -.726 & & & & \\
\hline & ethnicity & .022 & .417 & & & & \\
\hline & religion & -.016 & -.292 & & & & \\
\hline & Delinquency & .001 & .015 & & & & \\
\hline & Moral Neutralisation & $.237 * * *$ & 4.154 & & & & \\
\hline & Experience with police & $-.184 * *$ & -2.781 & & & & \\
\hline & Political cynicism & $-.216^{* * *}$ & -3.800 & & & & \\
\hline & Police corruption & $-.140 *$ & -1.970 & & & & \\
\hline & Police effectiveness & -.010 & -.183 & & & & \\
\hline & Procedural justice & $.174 * *$ & 3.146 & & & & \\
\hline
\end{tabular}

Independently, delinquency and moral neutralisation were both significant while none of the socio-demographic variables had significant influence on legitimacy. However, delinquency accounted for a higher Beta value $(\beta=-.203 ; p<.001)$ than moral neutralisation $(\beta=.181 ; p<$ $.05)$.

In the third step, experience with police, political cynicism, and police corruption were added to the model, a total variance of $17 \%[F(9,294)=6.464 ; p<.001]$ was explained by the model of which $11 \%\left(R^{2}\right.$ change $\left.=.107\right)$ was added by experience with police, political cynicism, and police corruption.

Independently, all the socio-demographics and delinquency variables were not significant predictors of police legitimacy. Whereas, moral neutralisation $(\beta=.223 ; p<.001)$ accounted for the highest Beta value in the analysis, followed by experience with police $(\beta=-.221 ; p<.001)$, political cynicism $(\beta=-.190 ; p<.001)$, and police corruption $(\beta=-.138 ; p<.05)$ respectively. The results showed that that those who were more likely to morally justify their actions held more positive views of police as legitimate. Those who had more negative experience with police, who had 
stronger cynicism about the political system, and who thought the police were more corrupt were less likely to view police as legitimate.

In the final stage of the analyses, police effectiveness and procedural justice were added to the model. The result showed that all the independent variables jointly account for $19.3 \%$ [ $F$ $(11,292)=6.331 ; p<.001]$ total variance in the analysis of which police effectiveness and

procedural justice explained $2.7 \%\left(R^{2}\right.$ change $\left.=.027\right)$. While procedural justice was a significant predictor of police legitimacy, the most important predictor was found to be moral neutralisation $(\beta=.237 ; p<.001)$, followed by political cynicism $(\beta=-.216 ; p<.001)$, experience with police $(\beta=-.184 ; p<.001)$, procedural justice $(\beta=.174 ; p<.01)$, and police corruption $(\beta=-.140 ; p<.05)$ respectively. In this model, socio-demographics, delinquency, and police effectiveness were not significant predictors of police legitimacy. Importantly, procedural justice was a more independent predictor of police legitimacy than police effectiveness.

\section{Discussion}

Scholarship on perceptions of police legitimacy and procedural justice among young people, especially from a transition society, is sporadic. However, research findings in developed western societies have shown that when young people perceive the police as treating them in a procedurally fair manner, they are more likely to view the police as legitimate. The aim of this study was to examine whether procedurally fair policing would foster positive perception of police legitimacy among the youths in a transition society riddled with high levels of police corruption. 
The result of this analysis has shown consistency with studies in the West. The regression analysis revealed that procedural justice had a significant effect on adolescents' perceptions of police legitimacy. It was established that young people who perceived police as using fair procedures were more likely to see police as legitimate. This result was not in support of the first hypothesis, as police effectiveness was not a significant predictor of police legitimacy. It was, however, consistent with both youth and adult studies in the West; confirming that procedural justice was more important than police effectiveness in predicting perceptions of police legitimacy (Hinds, 2007; Fagan and Tyler, 2005; Piquero et al., 2005; Murphy, 2015).

This study has revealed that in Nigeria procedural fairness is important among young people. This is conflicting with previous research conducted in other African countries. In those studies, police effectiveness was found to be more important in adult samples in Ghana and South Africa (see Tankebe, 2009a; Bradford et al., 2014). Why do young people place more emphasis on procedural justice in Nigeria than the adult population in Ghana and South Africa? After all, the policing situation in Ghana and South Africa is fairly similar to that of Nigeria; with high levels of corruption, abuse, and most importantly a high emphasis on crime control and effectiveness of its police force (Bradford et al., 2014; Tankebe, 2007; Tankebe, 2009b; Baker, 2004).

Given that with continuous ineffectiveness and corruption in the police, these young people might have relied more on alternative policing; thereby leading them to draw more heavily on their expectation of procedurally fair policing. It may also be that these young peoples' perceptions were mainly vicarious with little or no direct encounter with police so as to properly warrant their assessment of procedurally fair and effective policing. Further studies will be required to fully grasp the dichotomy between this finding and previous studies in Ghana and 
South Africa. That is, one may not be able to fully delineate why this is so until the effects of procedural justice policing is studied among an adult population in Nigeria.

In a bid to separate what the police do from the socio-political influence on the young people and who they are, other independent and control variables were incorporated into the analyses. Unlike previous youth and adolescent studies, perceptions of police corruption, personal experiences with police, political cynicism, delinquency, and moral neutralisation were included in the analyses. The data confirmed that the legitimacy of the police is linked to these other variables. Specifically, it was found that young people who had lower perceptions of police corruption more likely ascribed legitimacy to the police than their counterparts with higher perception of police corruption. This call into question the assertion of efficient grease theory regarding its premise that citizens faced with ill-functioning institutions will place greater trust in the political institutions if they believe corruption will open the door to inaccessible services. Contrary to this assumption, this study has shown that some of the young population in Nigeria are 'committed' to seeing a policing system void of corruption. Therefore, my third hypothesis is not supportive of efficient grease theory; police corruption will undermine police legitimacy (Newburn, 1999; Tankebe, 2010; Seligson, 2002).

This study also confirmed that young people with fewer experiences with police will likely ascribe greater legitimacy to the police. The result of their delinquency and moral neutralisation could possibly have implications for this outcome. In the first stage of the analyses, delinquency and moral neutralisation were found to significantly predict police legitimacy. However, in the subsequent analyses, delinquency did not show a significant effect while the effects of moral neutralisation increased significantly. The result showed that adolescents, who reported less delinquent tendencies, tend to ascribe more legitimacy to the 
police, whereas young people who "turned off" their internal moral control were more likely to view police as legitimate. This pattern could be shrouded in other reasons not covered in this study, but it should be noted that this might also be a result of the young people's underlying antisocial behaviour. This is because delinquents, especially those with high contact with legal institutions, most often believe that such social control institutions are not necessary (Piquero et al., 2005).

This study also advanced our understanding of how young people's cynicism about the political system influences their perceptions of police legitimacy. Accordingly, the result showed that young people who reported low political cynicism were more likely to view police as legitimate. This might be suggesting that the authority of the police might not be singularly judged by the citizen's perception of what they do, but most importantly failure of government and those in the leadership. It is often believed that when the political elites fail in their responsibilities, in meeting normative requirements of democratic leadership, the spill over effect will be catastrophic to the legitimacy of legal institutions (Becquart-Leclercq, 1989). This is no doubt the situation in Nigeria, where people holding political positions tend to be dominated by people of questionable character. Since the advent of democracy in Nigeria in 1999, the successive administration has shown that the dividend of democracy is solely meant for the few political elites. There is a high level of resentment from the public and to avoid attacks or questions from angry citizens, politicians resort to the use of police as armed bodyguards. This attempt at dragging police into their political mess has further alienated the citizens from the police, at the same time pushing the police further away from democratic policing or accountability. 
Although the findings presented in this article established that young peoples' perceptions of police legitimacy was not solely predicted by procedural justice, but by many other associated factors. In fact, these other variables in the model were stronger predictors of police legitimacy than procedural justice. However, procedural justice is still an important factor in the legal socialisation of Nigerian youth, and using procedural justice, police can differentiate themselves from the corrupt political system. Implementing a procedurally fair police force may further help Nigerian youth to have better contact with the police. This may leave them feeling more respected and valued by the police as important members of their community. More so, positive and affirming treatment by the police might positively influence future positive attitudes and behaviours directed toward police.

\section{Conclusion}

Although limitations exist in this study, these do not detract from its relevance to the procedural justice literature. The current investigation has shown that in Nigeria, procedural justice may be beneficial when police relate with young people. By doing so, police will be able to shape adolescents' perceptions of police legitimacy. If it is possible to infer judgement between this current investigation and that of Ghana or South Africa, one may begin to assume that there may be an occurrence of a subtle generational shift in public expectations of the police in Nigeria. The expectations of youth in Nigeria skews towards procedurally just and fair treatment being important; this is a significant shift from the instrumental expectations of police effectiveness in the Ghanaian and South African adult samples. 


\section{References}

Agbu O. (2003) Corruption and human trafficking: the Nigerian case. West Africa Review 4: 1-13.

Akinlabi OM. (2011) Legitimacy, Corruption and Delinquency: A Study of Adolescents' Perceptions and Behaviour in Nigeria. Cambridge: University of Cambridge.

Alemika EO. (1988) Policing and Perceptions of Police in Nigeria. Police Studies 11: 161 - 176.

Alemika EO. (2010) History, Context and Crises of the Police in Nigeria. Repositioning the Nigeria Police to Meet the Challenges of the Policing a Democratic Society in the Twenty-First Century and Beyond. Uyo, Akwa Ibom, Nigeria: Unpublished Presentation at the Biennial Retreat of the Nigeria Police Service Commission.

Alemika EO and Chukwuma IC. (2003) Civilian Oversight and Accountability of Police in Nigeria. Lagos: Centre for Law Enforcement Education (CLEEN).

Aremu AO, Pakes F and Johnston L. (2009) Locus of control and self-efficacy as means of tackling police corruption in Nigeria. International Journal of Police Science \& Management 11: 97-107.

Baker B. (2004) Protection from Crime: What is on Offer for Africans? Journal of Contemporary African Studies 22: 165 - 188.

Barclay E, Hogg R and Scott J. (2007) Young People and Crime in Rural Communities. In: Scott J, Hogg R, Barclay E, et al. (eds) Crime in rural Australia. Sydney: The Federation Press, 100 - 112.

Becquart-Leclercq J. (1989) Paradoxes of Political Corruption: A French View. In: Heidenheimer AJ, Johnston M and LeVine VT (eds) Political Corruption: A Handbook, Transaction. New Brunswick, New Jersey: Transaction Publisher, 191-210.

Beetham D. (1991) The Legitimation of Power, London: Palgrave Macmillan.

Beetham D. (2001) Legitimacy. In: Clarke PB and Foweraker J (eds) Encyclopedia of Democratic Thought. New York: Routledge. 
Bottoms A and Tankebe J. (2012) Beyond Procedural Justice: A Dialogic Approach to Legitimacy in Criminal Justice. Journal of Criminal Law and Criminology 102: 119-170.

Bradford B, Huq A, Jackson J, et al. (2014) What price fairness when security is at stake? Police legitimacy in South Africa. Regulation \& governance 8: 246-268.

Bradford B and Jackson J. (2010) Different Things to Different People? The Meaning and Measurement of Trust and Confidence in Policing across Diverse Social Groups in London. Social Science Research Network.

Cherney A and Murphy K. (2011) Understanding the Contingency of Procedural Justice Outcomes. Policing 5: 228-235.

CHRI Report. (2005) Police Accountability : Too Important to Neglect, Too Urgent to Delay.

Clark JP and Wenninger EP. (1964) The attitude of juveniles toward the legal institution. The Journal of Criminal Law, Criminology, and Police Science: 482-489.

Coicaud J-M. (2002) Legitimacy and Politics: A Contribution to the Study of Political Right and Political Responsibility, Cambridge: Cambridge University Press.

Cunneen C and White R. (2002) Juvenile Justice: Youth and Crime in Australia, Victoria: Oxford University Press.

Davies SG, Meliala A and Buttle J. (2014) Gangnam Style versus Eye of the Tiger: people, police and procedural justice in Indonesia. Policing and Society: 1-22.

Dike VE. (2005) Corruption in Nigeria: A new paradigm for effective control. Africa Economic Analysis.

Dirikx A and Van den Bulck J. (2014) Media use and the Process-Based Model for Police Cooperation An Integrative Approach towards Explaining Adolescents' Intentions to Cooperate with the Police. British Journal of Criminology 54: 344-365.

Easton D and Dennis J. (1969) Children in the Political System: Origins of Political Legitimacy, New York: McGraw-Hill.

Eisner M and Ghuneim L. (2013) Honor killing attitudes amongst adolescents in Amman, Jordan. Aggressive behavior 39: 405-417.

Eisner M and Nivette A. (2013) Does Low Legitimacy Cause Crime? A Review of the Evidence*.

Ericson RV and Haggerty KD. (1997) Policing the Risk Society, Oxford: Oxford University Press.

Fagan J and Tyler TR. (2005) Legal socialization of children and adolescents. Social Justice Research 18: 217-241.

Field A. (2013) Discovering statistics using IBM SPSS statistics, London: Sage.

Hills A. (2008) The Dialectic of Police Reform in Nigeria. Journal of Modern African Studies 46: 215 - 234.

Hinds L. (2007) Building Police-Youth Relationships: The Importance of Procedural Justice. Youth Justice 7: 195-209.

Hinds L. (2009) Youth, police legitimacy and informal contact. Journal of Police and Criminal Psychology 24: 10-21.

Hinds L and Murphy K. (2007) Public Satisfaction with Police: Using Procedural Justice to Improve Police Legitimacy. Australian and New Zealand Journal of Criminology 40: 27 - 43.

Hough M, Jackson J and Bradford B. (2013) Legitimacy, trust and compliance: An empirical test of procedural justice theory using the European Social Survey. Legitimacy and Criminal Justice: An International Exploration, Oxford: Oxford University Press.

Human Rights Watch H. (2010) 'Everyone's in on the Game': Corruption and Human Rights Abuses by the Nigeria Police Force. Available at: http://www.hrw.org/en/news/2010/08/17/nigeriacorruption-fueling-police-abuses.

Huntington SP. (2006) Political order in changing societies, New Haven: Yale University Press.

Jackson J, Asif M, Bradford B, et al. (2014) Corruption and Police Legitimacy in Lahore, Pakistan. British Journal of Criminology 54: 1067-1088. 
Jackson J, Bradford B, Hough M, et al. (2012) Why do People Comply with the Law? Legitimacy and the Influence of Legal Institutions. British Journal of Criminology 52: 1051-1071.

Jackson J, Hough M, Bradford B, et al. (2015) Empirical Legitimacy as Two Connected Psychological States. In: Meško G and Tankebe J (eds) Trust and Legitimacy in Criminal Justice. Springer, 137160.

Kochel TR. (2012) Can police legitimacy promote collective efficacy? Justice Quarterly 29: 384-419.

Kochel TR, Parks R and Mastrofski SD. (2013) Examining police effectiveness as a precursor to legitimacy and cooperation with police. Justice Quarterly 30: 895-925.

Lavallée E, Razafindrakoto $M$ and Roubaud F. (2008) Corruption and trust in political institutions in subSaharan Africa. CSAE Conference 2008 - Economic Development in Africa. Oxford.

Leff NH. (1964) Economic development through bureaucratic corruption. American behavioral scientist 8: 8-14.

Leiber MJ, Nalla MK and Farnworth M. (1998) Explaining juveniles' attitudes toward the police. Justice Quarterly 15: 151-174.

Leys C. (1965) What is the Problem about Corruption? The Journal of Modern African Studies 3: 215-230.

Loader I. (1996) Youth, Policing and Democracy, London: Palgrave Macmillan.

Mabogunje AL. (1967) The Morphology of Ibadan. In: Lloyd PC, Mabogunje AL and Awe B (eds) The City of Ibadan: A Symposium on its Structure and Development New York: Cambridge University Press, 35 - 58.

Mastrofski SD, Snipes JB and Supina AE. (1996) Compliance on Demand: the Public's Response to Specific Police Requests. Journal of Research in Crime and Delinquency 33: 269-305.

Matheson C. (1987) Weber and the Classification of Forms of Legitimacy. British Journal of Sociology: 199-215.

Mazerolle L, Antrobus E, Bennett S, et al. (2013) Shaping Citizen Perceptions of Police Legitimacy: A Randomized Field Trial of Procedural Justice. Criminology 51: 33-63.

Mazerolle L, Bennett S, Antrobus E, et al. (2012) Procedural justice, routine encounters and citizen perceptions of police: main findings from the Queensland Community Engagement Trial (QCET). Journal of Experimental Criminology 8: 343-367.

Mazerolle L and Martin P. (2012) Evidence-Based Policing and Procedural Justice. Journal of California Law Enforcement 46: 13.

McCluskey JD. (2003) Police Requests for Compliance: Coercive and Procedurally Just Tactics, New York: LFB Scholarly Publishing LLC.

Murphy K. (2015) Does procedural justice matter to youth? Comparing adults' and youths' willingness to collaborate with police. Policing and Society 25: 53-76.

Murphy K and Cherney A. (2011) Fostering cooperation with the police: How do ethnic minorities in Australia respond to procedural justice-based policing? Australian \& New Zealand Journal of Criminology 44: 235-257.

Murphy K and Gaylor A. (2010) Policing youth: Can procedural justice nurture youth cooperation with police?: Alfred Deakin Research Institute, Deakin University Australia.

Newburn T. (1999) Understanding and Preventing Police Corruption: Lessons from the Literature. London: Home Office, Policing and Reducing Crime Unit, Research, Development and Statistics Directorate.

Nivette AE and Eisner M. (2013) Do legitimate polities have fewer homicides? A cross-national analysis. Homicide Studies 17: 3-26.

Odunsi BA. (2005) The Police and Human Rights Infractions: The Need for Reform. Nigeria in the TwentyFirst Century: Strategies for Political Stability and Peaceful Co-existence: 185-205. 
Osoba SO. (1996) Corruption in Nigeria: Historical Perspectives. Review of African Political Economy 23: $371-386$.

OYSG. (2013) Oyo State Government, Federal Republic of Nigeria. Available at: http://oyostate.gov.ng/about-oyo-state.

Pallant J. (2010) SPSS Survival Manual: A Step By Step Guide to Data Analysis Using SPSS, Berkshire, England: McGraw-Hill.

Piquero AR, Fagan J, Mulvey EP, et al. (2005) Developmental Trajectories of Legal Socialisation among Serious Adolescent Offenders. The Journal of criminal law \& criminology 96: 267 - 298.

Reisig MD and Lloyd C. (2009) Procedural Justice, Police Legitimacy, and Helping the Police Fight Crime Results From a Survey of Jamaican Adolescents. Police Quarterly 12: 42-62.

Reisig MD, Tankebe J and Mesko G. (2012) Procedural Justice, Police Legitimacy, and Public Cooperation with the Police Among Young Slovene Adults. Journal of Criminal Justice and Security: 147-164.

Ribeaud D and Eisner M. (2010) Are Moral Disengagement, Neutralization Techniques, and Self-Serving Cognitive Distortions the Same? Developing a Unified Scale of Moral Neutralization of Aggression. International Journal of Conflict and Violence 4: 298 - 315.

Sanders WB. (1981) Juvenile Delinquency: Causes, Patterns, and Reactions, New York: Holt, Rinehart and Winston.

Sargeant E, Murphy K and Cherney A. (2014) Ethnicity, trust and cooperation with police: Testing the dominance of the process-based model. European Journal of Criminology 11: 500-524.

Schuck AM and Rosenbaum DP. (2005) Global and neighborhood attitudes toward the police: Differentiation by race, ethnicity and type of contact. Journal of Quantitative Criminology 21: 391-418.

Seligson MA. (2002) The impact of corruption on regime legitimacy: A comparative study of four Latin American countries. Journal of Politics 64: 408-433.

Smith DJ. (2007) A Culture of Corruption: Everyday Deception and Popular Discontent in Nigeria, New Jersey: Princeton University Press.

Sunshine J and Tyler TR. (2003) The Role of Procedural Justice and Legitimacy in Shaping Public Support for Policing. Law \& Society Review 37: 513-548.

Tabachnick BG and Fidell LS. (2013) Using Multivariate Statistics, Harlow, United Kingdom: Pearson.

Tamuno TN. (1970) The Police in Modern Nigeria, 1861-1965: Origins, Development and Role, Ibadan: Ibadan University Press.

Tankebe J. (2007) Policing and Legitimacy in a Post-Colonial Democracy: A Theoretical and Empirical Study of Ghana (Unpublished PhD Thesis). Institute of Criminology. Cambridge: University of Cambridge.

Tankebe J. (2009a) Public Cooperation with the Police in Ghana: Does Procedural Fairness Matter? Journal of Criminology 47: 1265 - 1293.

Tankebe J. (2009b) Self-Help, Policing, and Procedural Justice: Ghanaian Vigilantism and the Rule of Law. Law \& Society Review 43: 245-269.

Tankebe J. (2010) Public Confidence in the Police Testing the Effects of Public Experiences of Police Corruption in Ghana. British Journal of Criminology 50: 296-319.

Tankebe J. (2013) Viewing Things Differently: The Dimensions of Public Perceptions of Police Legitimacy. Criminology 51: 103-135.

Tyler TR. (1990) Why People Obey the Law, New Haven, CT: Yale University Press.

Tyler TR. (2004) Enhancing Police Legitimacy. Annals of the American Academy of Political and Social Science 593: 84-99.

Tyler TR. (2006a) Psychological perspectives on legitimacy and legitimation. Annual review of psychology 57: $375-400$. 
Tyler TR. (2006b) Why People Obey the Law, Princeton: Princeton University Press.

Tyler TR and Fagan J. (2008) Why do people cooperate with the police? Ohio State Journal of Criminal Law 6: 231-275.

Tyler TR and Huo YJ. (2002) Trust in the Law: Encouraging Public Cooperation with the Police and Courts, New York: Russell Sage Foundation.

Tyler TR and Lind EA. (1992) A relational model of authority in groups. Advances in experimental social psychology 25: 115-191.

Tyler TR and Murphy K. (2011) Procedural Justice, Police Legitimacy and Cooperation with the Police: A New Paradigm for Policing. Australian Research Council Centre of Excellence in Policing and Security Briefing Paper.

Weber M. (1947) The Theory of Economic and Social Organization, New York: The Free Press.

Williams D. (2003) Max Weber: Traditional, Legal-Rational, and Charismatic Authority.

Zimring FE and Johnson DT. (2005) On the comparative study of corruption. British Journal of Criminology 45: 793-809.

\section{Appendix A}

\section{ITEMS}

Mean SD

Police Legitimacy $($ Cronbach Alpha $=0.86)$

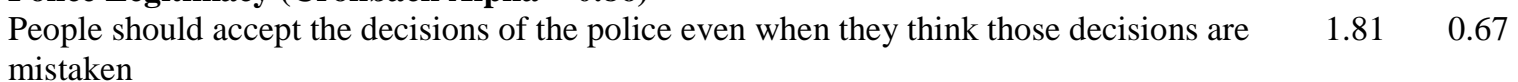

People should do what the police tell them to do, even when they don't understand why the order has been given

$1.83 \quad 0.55$

People should do what the police tell them to do, even when they disagree with the police

$2.02 \quad 0.81$

order

People should always do what the police tell them even when they don't like the way police

$2.03 \quad 0.78$

treat them

The Nigeria police are trustworthy

$\begin{array}{ll}2.05 & 0.83\end{array}$

I am proud of the police in Nigeria

$2.12 \quad 0.77$

I have confidence in the Nigeria police

$2.06 \quad 0.83$

The Nigeria police are often honest

2.10

0.88

The Nigeria police always act within the law

$2.31 \quad 0.86$

It is alright to sometimes ignore police decisions (R)

$\begin{array}{ll}2.71 & 0.97\end{array}$

The Nigeria police do not act to protect my interests (R)

$2.87 \quad 0.99$

The law represents those in power, and not the people values of people like me (R)

$2.35 \quad 1.08$

\section{Delinquency Scale $($ Cronbach Alpha $=\mathbf{0 . 8 1})$}

Not attended school without your parents knowing

$2.07 \quad 0.90$

Run away from home for a night or more

$2.03 \quad 0.83$

Stolen something on the market, in a shop or a supermarket

$1.55 \quad 0.66$

Stolen something at school (e.g. a pen)

$1.47 \quad 0.64$

Threatened somebody with a weapon (e.g. a stick or a knife) to get something you wanted Hit and injured another person

$1.46 \quad 0.66$

$1.48 \quad 0.68$ 
Participated in a serious fight with another group of adolescents

Smoked cannabis

$\begin{array}{ll}1.51 & 0.68 \\ 1.31 & 0.60 \\ 1.52 & 0.69 \\ 1.56 & 0.80 \\ 1.07 & 0.31 \\ 1.39 & 0.70\end{array}$

Been drunk

Used counterfeit money to pay for something

Had thrown stones or object during fight or argument

It is alright to beat somebody who doesn't respect your friends.

$2.19 \quad 0.88$

Sometimes it's okay to bully other people.

$2.09 \quad 0.92$

Bullying is just a normal part of being a kid.

$2.04 \quad 0.94$

People sometimes need to be bashed.

$2.06 \quad 0.93$

Only a coward would ever walk away from a fight.

$2.06 \quad 0.93$

It's ok to get in a physical fight with someone if you have to stand up to protect your rights. $2.07 \quad 0.90$

Many problems can be solved with violence.

$1.95 \quad 0.88$

Some kids need to be picked on just to teach them a lesson.

$2.20 \quad 0.91$

Getting bullied helps make people tougher.

$2.11 \quad 0.87$

If someone acts like a jerk, it is ok to treat them badly.

Some kids get bullied because they deserve it.

$2.10 \quad 0.91$

$2.18 \quad 0.86$

Most students who get bullied bring it on themselves.

You should hurt people first, before they hurt you.

$2.07 \quad 0.93$

It's ok to slag other people off, they slag you off too.

$2.14 \quad 1.05$

$2.30 \quad 0.92$

\section{Experience with Police $($ Cronbach Alpha $=0.71)$}

Have you contacted the police to report a crime

Have you been stopped by the police on the street or on the way to school

Have you ever been arrested

$1.35 \quad 0.59$

You have been questioned as a witness

$1.52 \quad 0.54$

Have you asked a police officer for information or help

$1.53 \quad 0.57$

Has someone close to you had encounter with the police

1.43

0.53

Has someone you know been arrested by the police

1.32

0.54

Have you witnessed a situation where the police misbehaved

2.00

1.11

Political Cynicism (Cronbach Alpha = 0.90)

Nigerian politicians make promises during campaign and never fulfil their promises after

winning the election

Nigerian politicians are selfish and are more concerned about looting the treasury without

In order to get into politics or get nominated, most politicians would have to compromise

and make undesirable commitments

One is likely to become a politician in Nigeria if you have strong political godfather

\section{Police Corruption $($ Cronbach Alpha = 0.81)}

Nigeria police take bribes?

Nigeria police is known to deliberately provide false evidence to the courts 
Nigeria police extorts money from people?

Police Effectiveness (Cronbach Alpha = 0.76)

The police respond promptly to calls about crime (e.g. robbery, assault)

$1.44 \quad 0.57$

The police are always ready to provide satisfactory assistance to victims of crime

$1.56 \quad 0.59$

The police are always able to provide the assistance the public need from them

$1.65 \quad 0.57$

The police are doing well in controlling violent crime (e.g. armed robbery)

$1.39 \quad 0.60$

Crime levels in my neighbourhood have changed for the better in the last year

$1.50 \quad 0.66$

There are not many instances of crime in my neighbourhood

$1.66 \quad 0.61$

I feel safe walking in my neighbourhood at night due to police activities $\quad \begin{array}{ll}1.45 & 0.62\end{array}$

Overall, my neighbourhood is a good place to live in terms of security $\quad 1.61 \quad 0.56$

Overall, the police are doing a good job in my neighbourhood

$1.52 \quad 0.56$

When the police stop people they usually handle the situation well

$1.37 \quad 0.63$

Procedural Justice $($ Cronbach Alpha $=0.78)$

The police treat everyone with respect.

$1.65 \quad 0.58$

The police treat everyone with dignity

$1.66 \quad 0.64$

The police treat everyone equally

$1.99 \quad 0.80$

The police respect people's rights.

$1.53 \quad 0.58$

The police follow through on their decisions and promises they make $\quad 1.69 \quad 0.52$

The Nigeria police always act within the law

$1.60 \quad 0.55$

The police take account of the needs and concerns of people they deal with. $\quad 1.70 \quad 0.56$

The police sincerely try to help people with their problems $\quad 1.67 \quad 0.58$

$\begin{array}{lll}\text { The police clearly explain the reasons for their actions. } & 1.72 & 0.56\end{array}$

$\begin{array}{lll}\text { The police try to find the best solutions for people's problems. } & 1.70 & 0.57\end{array}$

$\begin{array}{lll}\text { The police provide opportunity for unfair decisions to be corrected. } & 1.68 & 0.66\end{array}$

The police use rules and procedures that are fair to everyone $\quad 1.71 \quad 0.55$ 